\title{
Assessment of Mercury Pollution in Rivers and Streams around Artisanal Gold Mining Areas of the Birim North District of Ghana
}

\author{
Vincent K. Nartey ${ }^{1}$, Raphael K. Klake ${ }^{1}$, Ebenezer K. Hayford ${ }^{2}$, Louis K. Doamekpor ${ }^{1}$, \\ Richard K. Appoh ${ }^{3}$ \\ ${ }^{1}$ Department of Chemistry, Faculty of Science, University of Ghana, Legon, Ghana; ${ }^{2}$ Department of Earth Science, Faculty of Sci- \\ ence, University of Ghana, Legon, Ghana; ${ }^{3}$ Environmental Science Programme, Faculty of Science, University of Ghana, Legon, \\ Ghana. \\ Email: vknartey@ug.gh.edu
}

Received August 19 $9^{\text {th }}$ 2011; revised September 25 ${ }^{\text {th }}, 2011$; accepted October $28^{\text {th }}, 2011$.

\begin{abstract}
Artisanal gold mining in local communities is on the increase. This has led to concerns about mercury pollution resulting from these mining activities. This study was conducted to assess the level of mercury pollution in rivers and streams around artisanal gold mining areas of the Birim North District of Ghana. Rivers, streams, sediments and boreholes were sampled to determine total mercury levels during the wet and dry seasons and to explore the potential impact of the mercury levels on water quality in the area. The results show that the total mercury concentrations measured upstream were significantly lower than concentrations in samples taken downstream. Also, the total mercury concentrations measured in the stream water samples in both seasons exceeded the WHO guideline limit $(1.0 \mu \mathrm{g} / \mathrm{L})$ for drinking water. However, one downstream total mercury concentration exceeded the guideline limit in the dry season. The total mercury concentrations in sediments upstream and downstream in both seasons exceeded the US-EPA guideline value of $0.2 \mathrm{mg} / \mathrm{kg}$. The boreholes in the study area have total mercury concentrations exceeding the WHO guideline limit during both seasons. Total mercury concentrations in the boreholes in the wet season were lower than the dry season.
\end{abstract}

Keywords: Mercury Pollution, Artisanal Gold mining, Birim North District, Ghana

\section{Introduction}

Mining has played a major role in the socio-economic and infrastructural development of most developing countries, particularly in Africa and especially Ghana which is the second largest gold producer in Africa [1].

Gold mining can be on large-scale and small-scale. The technique used depends on the scale, the type of deposit and its location [2]. Small scale mining has been on the increase in developing countries like Ghana. Mineral production from small-scale mining accounts for approximately one-sixth of global mineral output [3]. Direct employment by the small-scale mining sector in Ghana as at the end of 2006 was about 600,000 [1]. In 2007, about 239,331 ounces representing $9.6 \%$ of total gold production was recorded by the small-scale gold mining sector in Ghana [1].

Artisanal mining encompasses small, medium, informal, legal and illegal miners who use rudimentary techniques for mineral extraction and often operate under ha- zardous, labor-intensive and highly disorganized conditions. Despite these factors, artisanal mining is an essential activity in many developing countries, particularly in regions where economic alternatives are critically limited. In recent years, this sector has experienced unprecedented growth worldwide. In Ghana, where poverty rates remain high, small-scale mining has become the best earning opportunity for the economically active population [4].

The methods for extracting gold have varied during the years. Starting with simple small hand operations like gravity panning, there are now diverse techniques some of which are amalgamation and cyanide leaching [5]. The earlier methods of extracting visible gold without mercury or cyanide have less serious environmental impacts than the present methods. In all, artisanal gold mining is estimated to release up to 1350 tons of mercury to the global environment annually [6]. About 5.0 tons of mercury is released from small-scale mining operations in Ghana each year [3]. Mercury emissions from these 
activities are derived from poor practices, lack of knowledge about mercury toxicity and insufficient access to appropriate techniques. Environmental and health impacts resulting from the misuse of mercury and their effects on water bodies require coordinated actions and global responses. These responses can only come after there has been enough data on the level of mercury resulting from artisanal mining.

Available literature shows that there have not been past studies on the effects of artisanal mining on the levels of mercury in artisanal mining areas. To understand the scope and depth of the problems associated with artisanal mining, there is the need to study the levels of mercury in a location where artisanal mining takes place. One of these is the Birim area of Ghana. Most of the communities in the area get their domestic water supply from bore holes, rivers and streams. It is therefore imperative that the levels of mercury in these sources be known. Fishing is also a common phenomenon in these rivers and streams. The levels of mercury in these fishes can be used to safeguard the health of over a million people that rely on these rivers and streams for their fish supply. Knowledge of the mercury levels will also encourage remedial measures to be taken before the water is used for any purpose. The first objective of this study was to determine the levels of total mercury in rivers, streams, sediments and boreholes. Secondly, to compare the temporal and spatial variations in streams sediments and rivers. Thirdly to compare the levels of mercury in these samples with WHO guideline values.

\section{Materials and Methods}

\subsection{The Study Area}

The Birim North District is within latitude $6.15^{\circ} \mathrm{N}$ $6.35^{\circ} \mathrm{N}$ and longitude $0.20^{\circ} \mathrm{W}-1.05^{\circ} \mathrm{W}$. It is located in the western end of the Eastern Region of Ghana. The district with its capital at New Abirem is bordered by Kwahu West District to the north; Asante-Akyem South, Amansie East and Adansi South districts all to the west; Birim South District to the south; and Atiwa and Kwaebibirem districts to the east (Figure 1).

The district covers an estimated total land area of $1,250 \mathrm{~km}^{2}$ representing about $6.47 \%$ of the total land area of the Eastern Region. It is the second largest district in terms of land area after the Afram Plains District, in the Eastern Region [7].

\subsection{Climate}

The district lies within a wet semi-equatorial climatic zone and therefore experiences a double maxima rainfall pattern. The first rainfall season starts from late March and ends in early July. The second season also starts from mid August and ends in late October. The amount of rainfall received in the district is between 1500 and 2000 $\mathrm{mm}$ per annum. Temperatures range between a minimum of $25.2^{\circ} \mathrm{C}$ and a maximum of $27.9^{\circ} \mathrm{C}$. The district has a relative humidity of about $55.0 \%-59.0 \%$ throughout the year [7].

\subsection{Relief and Drainage}

The district is mostly undulating and hilly in nature. The hilly areas are underlain by lava flows and schist. The lower areas of the district are also underlain by phyllite and greywacke. The lower areas have relatively low rainfall compared with the hilly areas. The highest point in the district is the Kwasiakwasi Mountain (N 06 28'09.6" \& W $\left.00^{\circ} 54^{\prime} 44.3^{\prime \prime}\right)$ located in the Kwasiakwasi Forest Reserve and rises to a height of about $800 \mathrm{~m}$ above sea level. The Kwasiakwasi Forest Reserve is the source of streams such as Nyanoma, Nkwasua and Aprokuma.

The district is drained mainly by two rivers, the Pra and its tributary the Birim. The tributaries of these rivers in the district include the Nwi, Suten, Mamang, Adechensu, Sukrang, Nkwas ua, Nyanoma, Afosu, etc. All these rivers flow generally from the northeast to the southwest to join the Pra, which flows southwards and enters the sea at Shama in the Western Region. The Pra River serves as the boundary between the district and all the three districts in the Ashanti Region bordered to the west. Also, the Birim River serves as the southern boundary of the district [7].

\subsection{Geology and Hydrogeology}

The geology of the study area consists mainly of Proterozoic rocks of the Birimian (Upper and Lower Birimian) and Tarkwaian systems. Dixcove Granitoids Complex has intruded both the Birimian and Tarkwaian systems in many places in the district [8]. The Upper Birimian rocks consist of black slates, sericite schist and phyllites, with subordinate grey, sandy phyllites and grewackes. The lower Birimian rocks also consist of black phyllites, metasiltstones, metagreywackes, tuffaceous sediments, tuffs and hornstones [8].

The Tarkwaian system is chiefly sandstone, quartzite, phyllite, shale and conglomerate and is resting on and derived from the Birimian system [8]. The sandstone (a quartzite) consists of variable amounts of feldspar, sericite, chlorite, ferriferous carbonate, magnetite or hematite and epidote. The Tarkwa Phyllite consists of chloritoid and magnetite or hematite with sericite and chlorite [9]. The conglomerates consist of silicified Birimian greenstone and hornstone with minor jasper, quartz, quartzporphyry, tourmaline-quartz rocks with Birimian phyllites and schists in a matrix with quartz, feldspar, chlorite, 


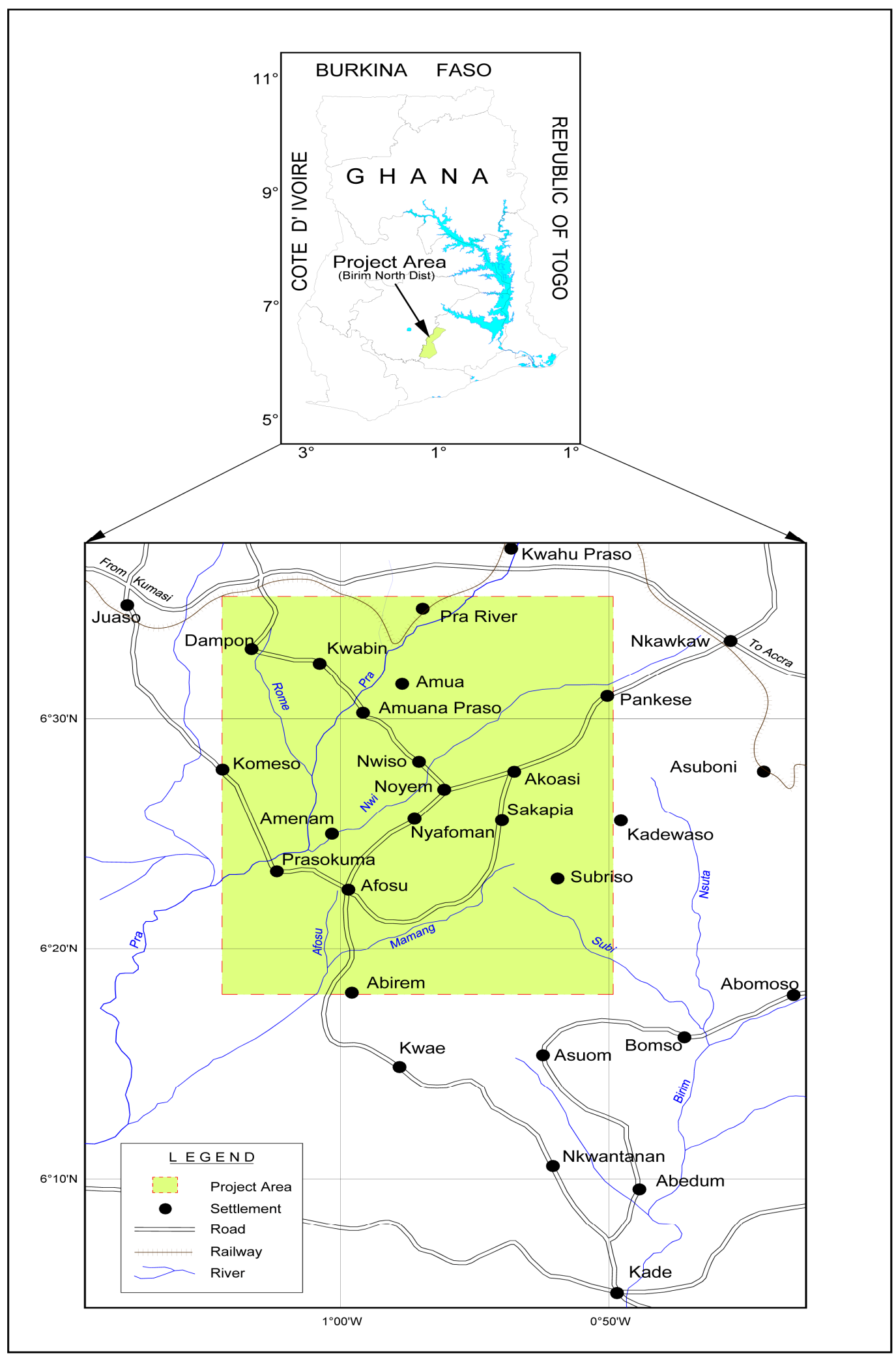

Figure 1. Map of the Study Area. 
carbonate, epidote, magnetite, chert and gondite [9].

The district lies almost wholly in the main mineral deposit area of the Eastern Region, accounting for the many small scale mining operations in gold and diamond. Groundwater is the main source of domestic water supply in the study area. Most of the towns/villages rely on groundwater with the exception of New Abirem and Afosu where surface water taken from the Pra and Afosu Rivers is treated and distributed. The underground water reserve is rich, despite the scarcity and inadequacy of potable water in many communities. Borehole yields in the study area are in the range of $1-5 \mathrm{~m}^{3} / \mathrm{hr}$. The rock underlying the area lack primary porosity since they are crystalline. Groundwater occurrence is therefore associated with the development of secondary porosity through fissuring and weathering.

Groundwater circulation in the study area is mainly localized due to the numerous mountains and hills that act as groundwater divides. Its flow is therefore mostly restricted to joints, fractures or other openings within the crystalline rock formations. In general, there are two types of aquifers: weathered rock aquifers and fractured rock aquifers. These aquifers tend to be either confined or semi-confined. Groundwater in the mining area is known to be vulnerable to pollution from mining and this may have serious effect on human health.

\subsection{Sampling Sites}

Even though the Birim North District has many rivers and streams, the artisanal gold mining areas where the study was conducted is drained by the Pra, Nwi, Suten, Sereman, Nyanoma, Nkwasua, Aprokuma and Tainsu rivers. Out of these, Pra, Nwi, Suten, Nyanoma, Nkwasua and Tainsu were selected because of their strategic locations in relation to the artisanal mining activities and their potential impact on domestic water supply in the area. The six boreholes sampled are located in the areas affected mostly by the mining activities. The sampling sites were given different designations as shown in Table 1. All the bore- holes have yields ranging from 1 - 3 $\mathrm{m}^{3} / \mathrm{hr}$ (Figure 2).

\subsection{Sampling Methodology}

\section{Environmental Data Sampling}

Sampling was designed to cover a 12 month period. The samples were collected between the months of April, 2009 and February, 2010. April, June and August were considered wet periods whilst October, December and February were considered as dry periods even though some rains occurred in the month of February.

Water and sediment sampling points were immediately upstream of the artisanal gold mining areas and near discharge areas of all the rivers/streams. The sam- pling points upstream of the artisanal gold mining areas were located at least $2 \mathrm{~km}$ from the artisanal gold mining area to prevent any possible contamination. The sampling points near the discharge areas were also located about $100 \mathrm{~m}$ upstream of the junction with the receiving water body. In the case of River Nwi, a first order tributary of River Pra, samples were taken about $1 \mathrm{~km}$ upstream of its first tributary in the mining area and also $100 \mathrm{~m}$ upstream of the confluence with River Pra. Water and sediment samples from River Pra were taken about 2 $\mathrm{km}$ upstream before it enters the mining area and about 2 $\mathrm{km}$ downstream of the mining area. Two boreholes were selected at each mining town/village and water samples taken.

At each river/stream sampling point, about $300 \mathrm{~cm}^{3}$ of water were taken from the centre of the stream/river at a depth of about 10 to $20 \mathrm{~cm}$ below the water surface. Sediment samples weighing about $300 \mathrm{~g}$ were also scooped below the water surface from the centre of the stream/ river. These were cleaned of wood pieces, pebbles, shells, leaves, etc. The borehole water samples were collected directly from the well heads. The borehole pipe should have been emptied by pumping before taking the sample but because these boreholes are almost continuously working throughout the day, the samples were collected directly. The water samples were kept in pre-labelled polypropylene bottles which have been rinsed with $10.0 \% \mathrm{HNO}_{3}$. About $3 \mathrm{~cm}^{3}$ of concentrated $\mathrm{HNO}_{3}$ was added to the water samples before its cap was fitted in order to stabilize the mercury content, because trace mercury is relatively stable at lower $\mathrm{pH}$ [10]. The sediment samples were put in pre-labelled transparent polythene bags. The bags were tied, put into a second polythene bag and sealed with duct tape. All the samples were stored in an ice chest with ice to maintain a low temperature $\left(<4^{\circ} \mathrm{C}\right)$ during transportation to the Environmental Chemistry Laboratory of the Water Research Institute for total mercury analysis.

\subsection{Laboratory Analyses}

The laboratory analyses were undertaken according to procedures outlined by APHA, AWWA and WEF 1998) [11]. Total mercury analysis was done at the Environmental Chemistry Laboratory of the Water Research Institute by Cold-Vapour Atomic Absorption Spectroscopy (CVAAS).

\subsubsection{Water Analyses}

About $100 \mathrm{~cm}^{3}$ each of the water samples was transferred into $125 \mathrm{~cm}^{3}$ conical flask. Approximately $5 \mathrm{~cm}^{3}$ of concentrated $\mathrm{HNO}_{3}$ was added and heated in a water bath at $95^{\circ} \mathrm{C}$ for about one hour. It was filtered, cooled and transferred into a $100 \mathrm{~cm}^{3}$ volumetric flask and diluted to the mark. A working solution of $0.1 \mathrm{mg} / \mathrm{L}$ was prepared 


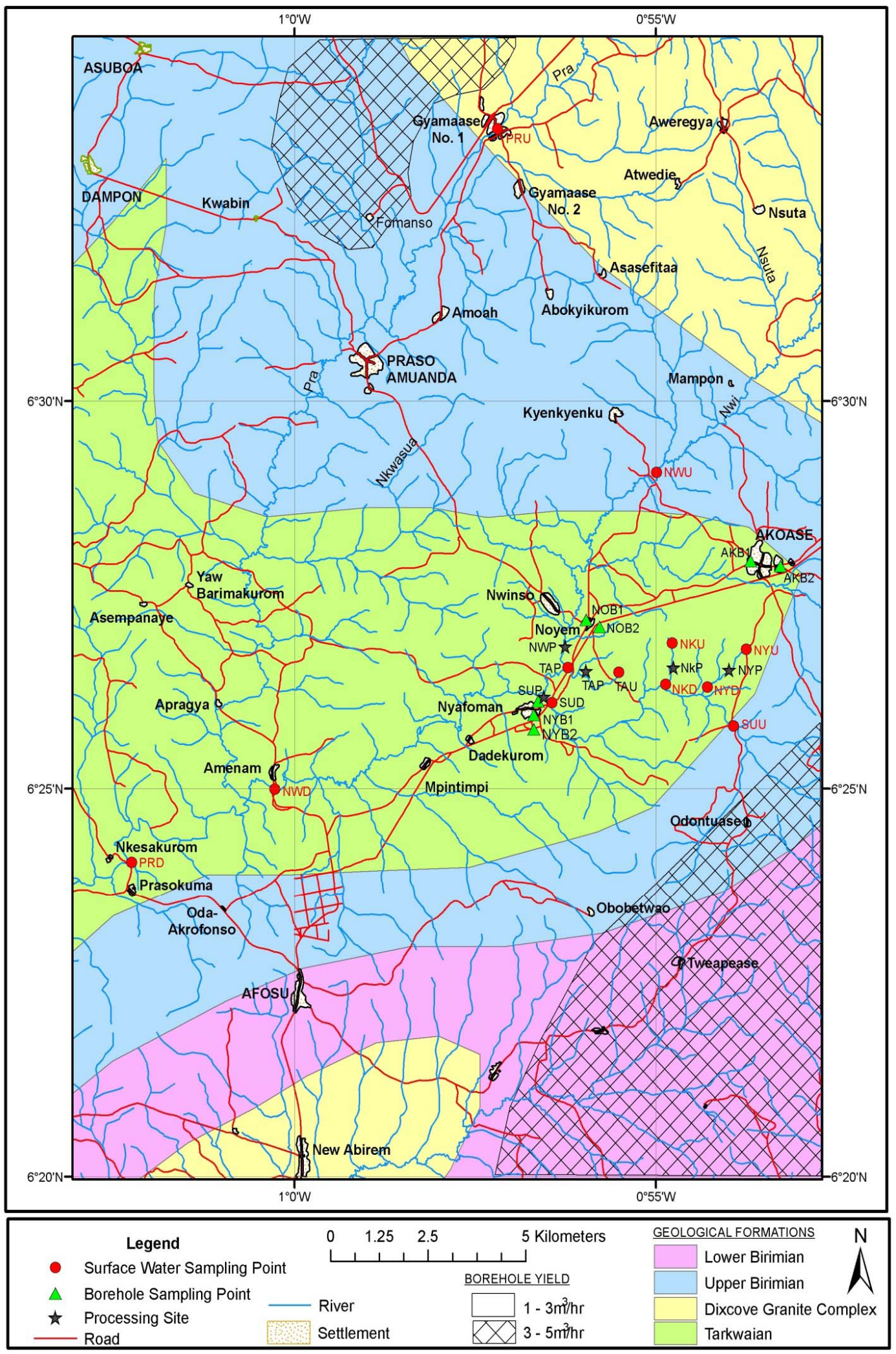

Figure 2. Hydrogeological Map of the Study Area Showing Sampling Points. 
Table 1. Geographical Location of Sampling Sites.

\begin{tabular}{|c|c|c|c|}
\hline Sampling Site & Designation & Name of Area & GPS Position \\
\hline \multicolumn{4}{|l|}{ Rivers/Streams } \\
\hline Upstream of Nyanoma Stream & NYU & Nyahnoma Hill & $\begin{array}{l}\text { N } 06^{\circ} 26^{\prime} 50.2^{\prime \prime} \\
\text { W } 00^{\circ} 53^{\prime} 45.3\end{array}$ \\
\hline Downstream of Nyanoma Stream & NYD & Sakapia & $\begin{array}{l}\text { N } 06^{\circ} 26^{\prime} 25.4^{\prime \prime} \\
\text { W } 00^{\circ} 54^{\prime} 00.4^{\prime \prime}\end{array}$ \\
\hline Upstream of Nkwasua Stream & NKU & Nkwasua Hill & $\begin{array}{l}\text { N } 06^{\circ} 26^{\prime} 51.1^{\prime \prime} \\
\text { W } 00^{\circ} 54^{\prime} 44.4^{\prime \prime}\end{array}$ \\
\hline Downstream of Nkwasua Stream & NKD & Noyem & $\begin{array}{l}\text { N } 06^{\circ} 26^{\prime} 27.4^{\prime \prime} \\
\text { W } 00^{\circ} 54^{\prime} \text { '50.5" }\end{array}$ \\
\hline Upstream of Tainsu Stream & TAU & Nyafoman & $\begin{array}{l}\text { N } 06^{\circ} 26^{\prime} 27.5^{\prime \prime} \\
\text { W } 00^{\circ} 55^{\prime} 51.2^{\prime \prime}\end{array}$ \\
\hline Upstream of of Suten Stream & SUU & Sakapia & $\begin{array}{l}\text { N } 06^{\circ} 25^{\prime} 51.6^{\prime \prime} \\
\text { W } 00^{\circ} 53^{\prime} 55.8^{\prime \prime}\end{array}$ \\
\hline Downstream of Suten Stream & SUD & Nyafoman & $\begin{array}{l}\text { N } 06^{\circ} 26^{\prime} 07.0^{\prime \prime} \\
\text { W } 00^{\circ} 56^{\prime} 28.7^{\prime \prime}\end{array}$ \\
\hline Upstream of Nwi River & NWU & Mampong & $\begin{array}{l}\text { N } 06^{\circ} 28^{\prime} 57.2^{\prime \prime} \\
\text { W } 00^{\circ} 55^{\prime} 00.8^{\prime \prime}\end{array}$ \\
\hline Downstream of Nwi River & NWD & Amenam & $\begin{array}{l}\text { N } 06^{\circ} 24^{\prime} 59.2^{\prime \prime} \\
\text { W } 01^{\circ} 00^{\prime} 18.2^{\prime \prime}\end{array}$ \\
\hline Upstream of Pra River & PRU & Jamasi & $\begin{array}{l}\text { N } 06^{\circ} 33^{\prime} 31.0^{\prime \prime} \\
\text { W } 00^{\circ} 57^{\prime} 11.8^{\prime \prime}\end{array}$ \\
\hline Downstream of Pra River & PRD & Prasokuma & $\begin{array}{l}\text { N } 06^{\circ} 24^{\prime} 00.3^{\prime \prime} \\
\text { W } 01^{\circ} 02^{\prime} 26.2^{\prime \prime}\end{array}$ \\
\hline \multicolumn{4}{|l|}{ Boreholes } \\
\hline Borehole at Akoasi 1 & AKB 1 & Akoasi & $\begin{array}{l}\text { N } 06^{\circ} 27^{\prime} 54.3^{\prime \prime} \\
\text { W } 00^{\circ} 53^{\prime} 42.0^{\prime \prime}\end{array}$ \\
\hline Borehole at Akoasi 2 & AKB 2 & Akoasi & $\begin{array}{l}\text { N } 06^{\circ} 27^{\prime} 51.2^{\prime \prime} \\
\text { W } 00^{\circ} 53^{\prime} 13.6^{\prime \prime}\end{array}$ \\
\hline Borehole at Noyem 1 & NOB 1 & Noyem & $\begin{array}{l}\text { N } 06^{\circ} 27^{\prime} 09.6^{\prime \prime} \\
\text { W } 00^{\circ} 55^{\prime} 57.4^{\prime \prime}\end{array}$ \\
\hline Borehole at Noyem 2 & NOB 2 & Noyem & $\begin{array}{l}\text { N } 06^{\circ} 27^{\prime} 06.5^{\prime \prime} \\
\text { W } 00^{\circ} 55^{\prime} 44.4^{\prime \prime}\end{array}$ \\
\hline Borehole at Nyafoman 1 & NYB 1 & Nyafoman & $\begin{array}{l}\text { N } 06^{\circ} 25^{\prime} 57.2^{\prime \prime} \\
\text { W } 00^{\circ} 56^{\prime} 40.7 "\end{array}$ \\
\hline Borehole at Nyafoman 2 & NYB 2 & Nyafoman & $\begin{array}{l}\text { N } 06^{\circ} 25^{\prime} 48.2^{\prime \prime} \\
\text { W } 00^{\circ} 56^{\prime} 42.5^{\prime \prime}\end{array}$ \\
\hline \multicolumn{4}{|l|}{ Artisanal Mining/Processing Sites } \\
\hline Sakapia Site & & & $\begin{array}{l}\text { N } 06^{\circ} 26^{\prime} 31.3^{\prime \prime} \\
\text { W } 00^{\circ} 54^{\prime} 00.7 "\end{array}$ \\
\hline Noyem New Site & & & $\begin{array}{l}\text { N } 06^{\circ} 26^{\prime} 34.4^{\prime \prime} \\
\text { W } 00^{\circ} 54^{\prime} 44.3^{\prime \prime}\end{array}$ \\
\hline Nyafoman Site 1 & & & $\begin{array}{l}\text { N } 06^{\circ} 26^{\prime} 31.3^{\prime \prime} \\
\text { W } 00^{\circ} 56^{\prime} 42.5^{\prime \prime}\end{array}$ \\
\hline Nyafoman Site 2 & & & $\begin{array}{l}\text { N } 06^{\circ} 26^{\prime} 32.9^{\prime \prime} \\
\text { W 00 } \\
\end{array}$ \\
\hline Nyafoman Site 3 & & & $\begin{array}{l}\text { N } 06^{\circ} 26^{\prime} 05.7^{\prime \prime} \\
\text { W } 00^{\circ} 56^{\prime} 34.1^{\prime \prime}\end{array}$ \\
\hline
\end{tabular}


from a commercially prepared solution of $10 \mathrm{mg} / \mathrm{L}$. A calibration standard solution of 2.0, 5.0 and $10.0 \mu \mathrm{g} / \mathrm{L}$ were prepared from the working solution in $50 \mathrm{~cm}^{3}$ volume with the addition of $1 \mathrm{~cm}^{3}$ each of concentrated $\mathrm{HNO}_{3}$ and $1.0 \mathrm{~g}$ each of $\mathrm{NaCl}$. The samples and reference materials were prepared using the same methodology.

A $50 \mathrm{~cm}^{3}$ volume of blank and the calibration standards were transferred into flasks and $1.0 \mathrm{~cm}^{3}$ of $5.0 \%$ stannous chloride was then added. The absorbance signal was noted at both $30 \mathrm{~s}$ and $60 \mathrm{~s}$ for the blank and each calibration solution. A graph of absorbance against concentration was generated. The procedure was repeated for the samples alongside reference materials and the corresponding absorbance extrapolated from the graph to obtain the concentrations.

\subsubsection{Sediment Analyses}

The sediment samples were dried at a temperature of $80^{\circ} \mathrm{C}$ for about $12 \mathrm{hr}$. The cooled samples were ground, homogenised and sieved using $180 \mu \mathrm{m}$ aperture pore size sieve net. About $0.2 \mathrm{~g}$ of the dry samples were weighed into teflon tubes and $2 \mathrm{~cm}^{3}$ of concentrated $\mathrm{HNO}_{3}$ slowly added. One reference material (SD-M-2/TM marine sediment, IAEA) and two blanks were also treated in the same manner. The Teflon tubes were tightly closed, shaken and placed in stainless steel bombs. The stainless steel bombs were placed on a hot plate and heated at a temperature of $150^{\circ} \mathrm{C}$ continuously for six hours.

The samples together with the blank and reference material were allowed to cool to room temperature before releasing the pressure by opening the bomb. The samples were transferred into graduated polypropylene tubes. The Teflon tubes were rinsed three times with deionised water and the rinsed solution added to the samples in the polypropylene tubes. Solutions were then diluted with deionised water to $50 \mathrm{~cm}^{3}$ and mixed thoroughly. The particles were then allowed to settle overnight and the digested sample analysed using Unicam 969 Atomic Absorption Spectrometer (AAS).

\subsection{Quality Control}

Quality control samples including blanks and certified reference materials were prepared according to APHA, AWWA and WEF (1998) [11]. Certified reference materials were digested along with the samples to check the accuracy of the method. The reference material for the sediment samples was SD-M-2/TM marine sediment (IAEA) and that of the water samples was NIVA 0736, though not digested. A quality control standard was run routinely during the sample analysis to monitor instrument drift and overall quality of the analysis. Analysis of all blanks and certified reference materials showed no inherent bias in the method of analysis for total mercury.

\section{Results and Discussions}

All statistical analyses were performed using SPSS (version 17.0) for windows. Comparisons were made between upstream means and downstream means for both stream water and sediment samples. Comparisons were also made between wet and dry season means for stream water, borehole water and sediment samples. The paired sample t-test was used to test for differences in the means of mercury concentrations in the upstreams and downstreams of the rivers/streams as well as differences between wet and dry periods. A probability value of $\mathrm{p}<$ 0.05 was considered as statistically significant in this study.

Also, the results of the water samples were compared with the WHO guideline value $(1.0 \mu \mathrm{g} / \mathrm{L})$ for drinking water [12] and that of the sediment samples were compared with the US EPA guideline value of $0.2 \mathrm{mg} / \mathrm{kg}$ [13]. Finally, comparisons were made with results from studies conducted elsewhere with similar characteristics.

The results of total mercury analysis for the study period are presented in Tables 2-4, Figures 3-5. A comparison is made between the upstream and downstream means as well as the wet season and dry season means. The results are compared with studies conducted with similar characteristics. Also, the results of the water samples were compared with the WHO guideline value (1.0 $\mu \mathrm{g} / \mathrm{L}$ ) for drinking water [12] and that of the sediment samples are compared with the US EPA guideline value of $0.2 \mathrm{mg} / \mathrm{kg}$ [13]. The concentrations falling above these safe limits are identified and discussed.

Although there are clear guidelines of limit values for maximum metal concentrations in water, air and food, as yet there is no equivalent consensus of permissible levels of metals in soils and sediment. This arises primarily as a result of great uncertainties of metal dose-relationships in soil and sediment media and has resulted in bewildering and sometimes contradictory guideline values [14].

\subsection{Total Mercury in River/Stream Water}

All the total mercury concentrations recorded in the wet season were lower than the corresponding dry season concentrations with the exception of the upstream of the River Nwi where the dry season total mercury concentration $(0.311 \mu \mathrm{g} / \mathrm{L})$ was lower than the wet season total mercury concentration $(0.358 \mu \mathrm{g} / \mathrm{L})$, Table 2 . The difference in total mercury concentration between the wet and dry seasons was significant at $5.0 \%$, since probability calculated (0.001) is less than 0.05 .

This reveals systematic seasonal variations in total mercury concentrations. The increase in total mercury 
Table 2. Comparison of Mean Concentrations of Total Mercury $(\mu \mathrm{g} / \mathrm{L})$ in Stream/River Water Samples with Known Artisanal Gold Mining Sites in the World.

\begin{tabular}{cccc}
\hline This Study & Wet & Dry & Mean \\
\hline NYU & 0.250 & 0.383 & 0.317 \\
NYD & 0.578 & 0.672 & 0.625 \\
NKU & 0.146 & 0.331 & $\mathbf{0 . 2 3 9}$ \\
NKD & 0.282 & 0.987 & 0.635 \\
TAU & 0.113 & 0.349 & 0.231 \\
TAD & 0.872 & 1.343 & 1.108 \\
SUU & 0.167 & 0.412 & 0.290 \\
SUD & 0.541 & 0.694 & 0.618 \\
NWU & 0.358 & 0.311 & 0.335 \\
NWD & 0.674 & 0.822 & 0.748 \\
PRU & 0.045 & 0.248 & 0.147 \\
PRD & 0.370 & 0.643 & 0.507 \\
\hline
\end{tabular}

Table 3. Comparison of Mean Concentrations of Total Mercury in Borehole Water Samples with Known Artisanal Gold Mining Sites in the World.

\begin{tabular}{|c|c|c|c|}
\hline This Study & Wet & Dry & Mean \\
\hline AKB1 & 0.283 & 0.473 & 0.378 \\
\hline AKB2 & 0.383 & 0.437 & 0.410 \\
\hline NOB1 & 0.237 & 0.439 & 0.338 \\
\hline NOB2 & 0.078 & 0.390 & 0.234 \\
\hline NYB1 & 0.619 & 0.482 & 0.551 \\
\hline NYB2 & 0.146 & 0.301 & 0.224 \\
\hline \multicolumn{2}{|c|}{ Sampling Sites } & Hg Levels (ug/L) & Reference \\
\hline \multicolumn{2}{|c|}{ Borehole (Adaase) } & 4.00 & [14]. \\
\hline \multicolumn{2}{|c|}{ Adaase Borehole No. 162} & 2.00 & [14]. \\
\hline \multicolumn{2}{|c|}{$\begin{array}{l}\text { Dokyiwa Borehole No. } \\
238\end{array}$} & $<1.00$ & [14]. \\
\hline \multicolumn{2}{|c|}{$\begin{array}{l}\text { Dokyiwa Borehole No. } \\
291\end{array}$} & 1.00 & [14]. \\
\hline \multicolumn{2}{|c|}{ Ntonnsua Borehole } & 1.00 & [14]. \\
\hline \multicolumn{2}{|c|}{$\begin{array}{l}\text { New Bidiem Borehole No. } \\
110\end{array}$} & 1.00 & [14]. \\
\hline \multicolumn{2}{|c|}{$\begin{array}{l}\text { New Bidiem Borehole No. } \\
201\end{array}$} & $<1.00$ & [14]. \\
\hline \multicolumn{2}{|c|}{ Akatakyieso Borehole } & 1.00 & [14]. \\
\hline \multicolumn{4}{|c|}{ Other Nations with Active AGM } \\
\hline \multicolumn{2}{|c|}{ Paniki (Indonesia) } & 0.095 & [16]. \\
\hline \multicolumn{2}{|c|}{ Kumahukur (Indonesia) } & 0.090 & [16]. \\
\hline \multicolumn{2}{|c|}{ Malayalang (Indonesia) } & 0.070 & [16]. \\
\hline \multicolumn{2}{|c|}{ Koka (Indonesia) } & 0.095 & [16]. \\
\hline
\end{tabular}

Table 4. Comparison of Mean Concentrations of Total Mercury(mg/Kg) in Stream / River Sediment Samples with Known Artisanal Gold Mining Sites in the World.

\begin{tabular}{|c|c|c|c|}
\hline This Study & Wet & Dry & Mean \\
\hline NYU & 0.507 & 0.891 & 0.699 \\
\hline NYD & 1.628 & 2.184 & 1.906 \\
\hline NKU & 0.381 & 1.212 & 0.797 \\
\hline NKD & 1.852 & 4.745 & 3.299 \\
\hline TAU & 0.732 & 1.881 & 1.307 \\
\hline TAD & 2.323 & 4.886 & 3.605 \\
\hline SUU & 0.411 & 0.390 & 0.401 \\
\hline SUD & 1.308 & 3.769 & 2.539 \\
\hline NWU & 0.396 & 0.381 & 0.389 \\
\hline NWD & 0.758 & 2.807 & 1.783 \\
\hline PRU & 0.134 & 0.405 & 0.270 \\
\hline PRD & 0.401 & 1.415 & 0.908 \\
\hline Sampling & & (mg/kg) & Reference \\
\hline R. San (S & & & [14]. \\
\hline $\begin{array}{l}\text { R. Kwame } \\
\text { (Dokyi }\end{array}$ & & & [14]. \\
\hline R. Fena (Hi & & & [14]. \\
\hline $\begin{array}{r}\text { R. Fe } \\
\text { (Fenaso F }\end{array}$ & & & [14]. \\
\hline R. Fena (A & & & [14]. \\
\hline R. Fena (A & & & [14]. \\
\hline $\begin{array}{l}\text { River Kw } \\
\text { ( Kwabra }\end{array}$ & & & [14]. \\
\hline $\begin{array}{r}\text { River S } \\
\text { (Ntonn }\end{array}$ & & & [14]. \\
\hline Lower Pra & & & [15]. \\
\hline Upper Pra & & & \\
\hline Offin R & & & [15]. \\
\hline \multicolumn{4}{|c|}{ Other Nations with Active AGM } \\
\hline $\begin{array}{l}\text { South-wester } \\
\text { Basin (B }\end{array}$ & & & [17]. \\
\hline $\begin{array}{l}\text { Talawan W } \\
\text { (Indone }\end{array}$ & & & {$[18]$.} \\
\hline $\begin{array}{r}\text { Mindanao } \\
\text { (Philipp }\end{array}$ & & & [19]. \\
\hline
\end{tabular}

concentration during the dry season could be attributed to two things. The first is increased mining activities during the dry season with corresponding increase in mercury use. The other reason is the evaporation of surface water resulting in increased mercury concentrations. During the study period, there was no evidence of increased mining activities. Increase in total mercury concentration can therefore be wholly attributed to evapora- 


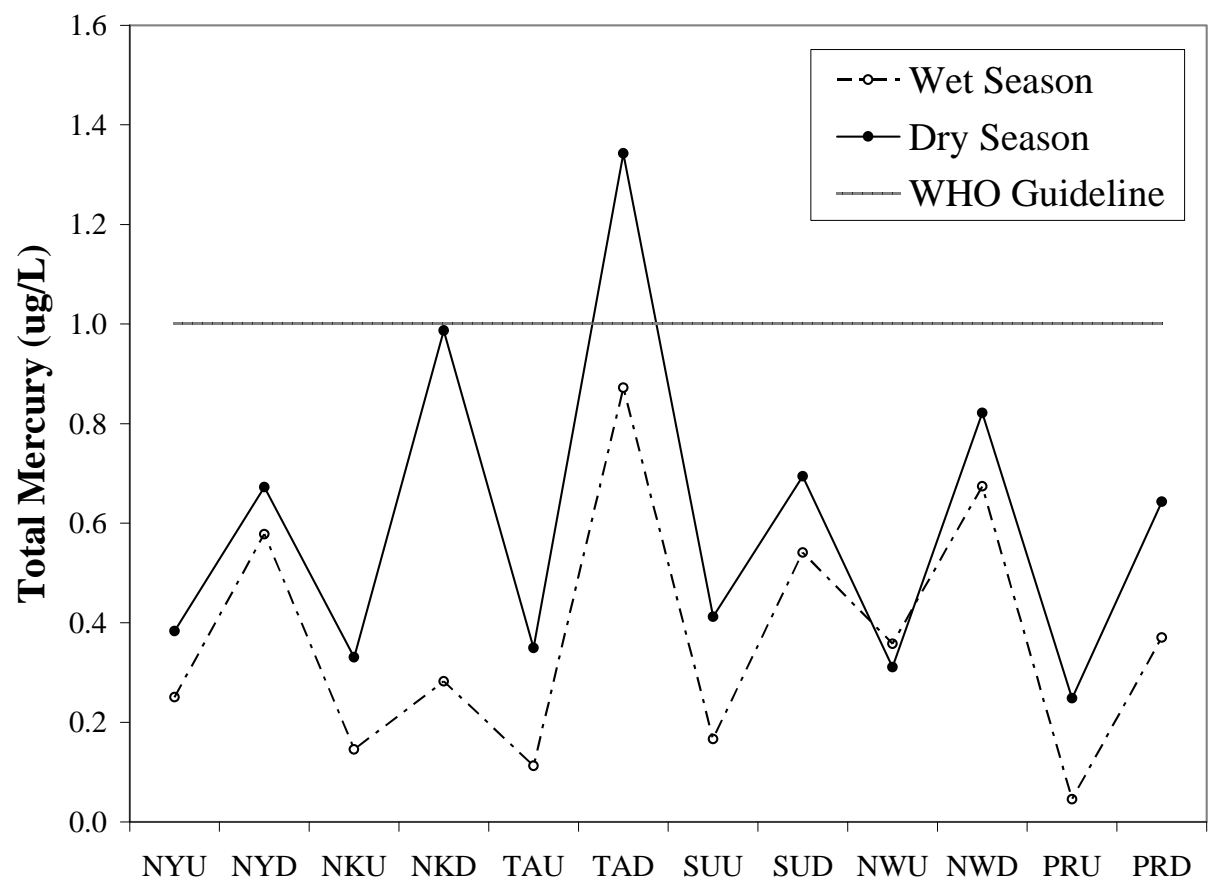

Sampling Points

Figure 3. Total Mercury Analysis of Stream/River Water Samples (NYU) = Upstream of Nyanoma Stream, (NYD) = Downstream of Nyanoma Stream, $(\mathrm{NKU})=$ Upstream of Nkwasua Stream, $(\mathrm{NKD})=$ Downstream of Nkwasua Stream, $($ TAU) $=$ Upstream of Tainsu Stream, (TAD) = Downstream of Tainsu Stream, (SUU) = Upstream of Suten Stream, (SUD) = Downstream of Suten Stream, (NWU) = Upstream of Nwi River, $($ NWD) = Downstream of Nwi River, $($ PRU) $=$ Upstream of Pra River, $($ PRD $)=$ Downstream of Pra River.

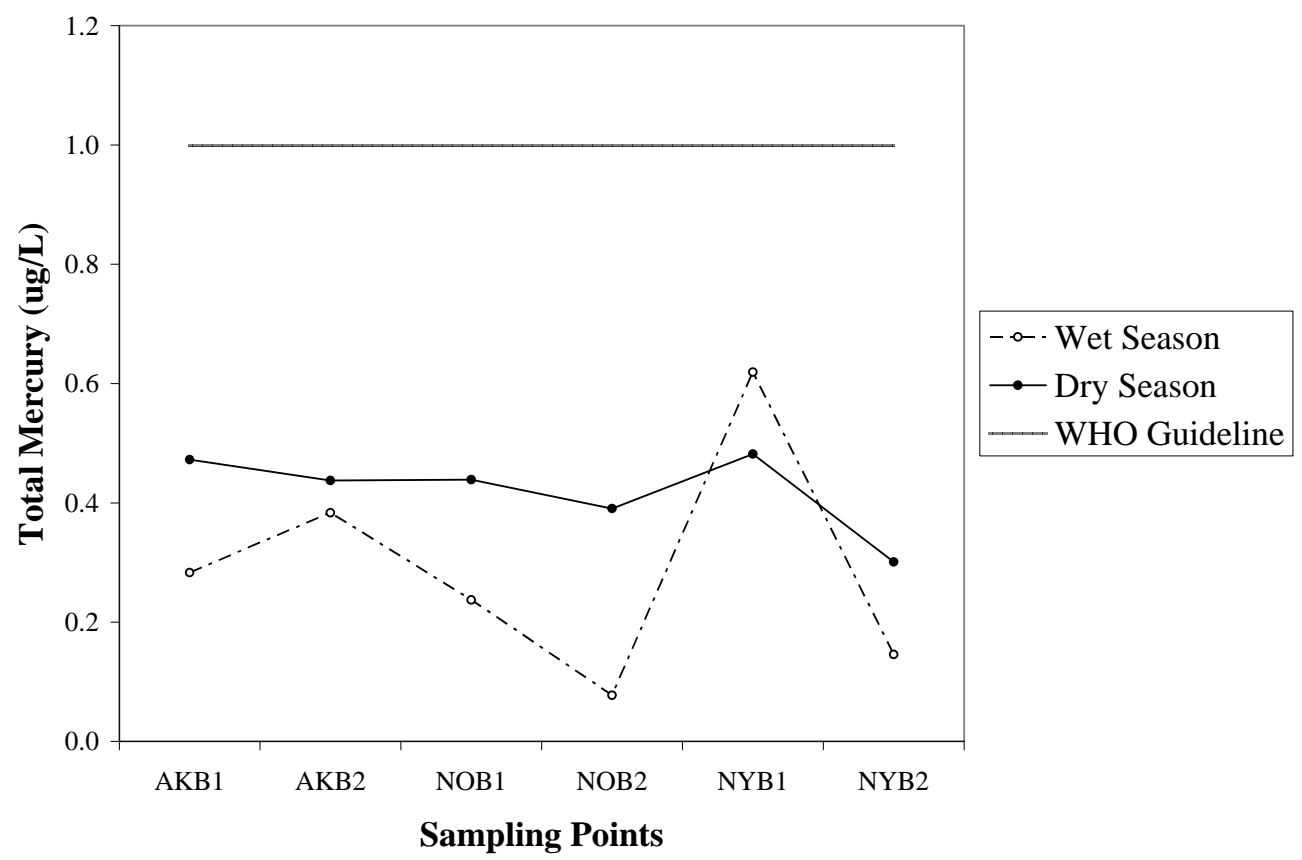

Figure 4. Total Mercury Analysis of Borehole Water Samples $(\mathrm{AKB1})=$ Borehole at Akoasi 1, $(\mathrm{AKB} 2)=$ Borehole at Akoasi 2 , $($ NOB1 $)=$ Borehole at Noyem 1, $($ NOB2 $)=$ Borehole at Noyem $2,($ NYB1 $)=$ Borehole at Nyafoman $1,($ NYB2 $)=$ Borehole at Nyafoman 2. 


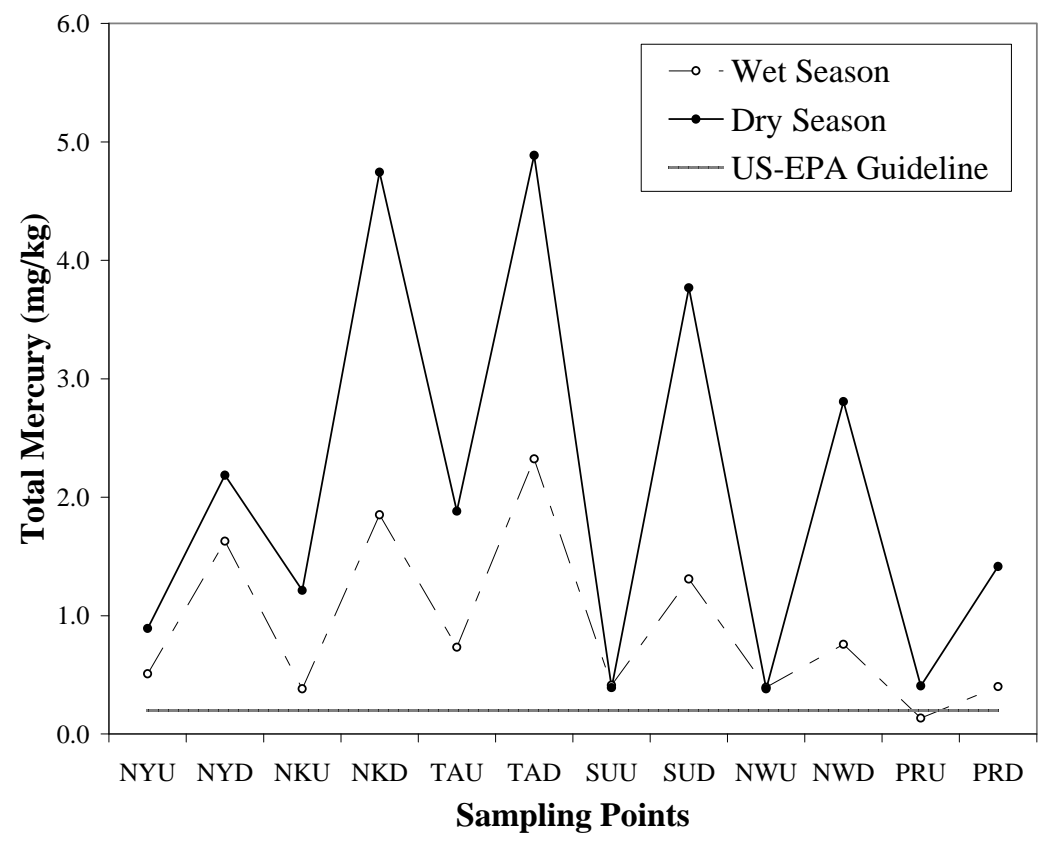

Figure 5. Total Mercury Analysis of Stream/River Sediment Samples (NYU) = Upstream of Nyanoma Stream, $($ NYD) $=$ Downstream of Nyanoma Stream, $(\mathrm{NKU})=$ Upstream of Nkwasua Stream, $($ NKD) $=$ Downstream of Nkwasua Stream, $($ TAU) = Upstream of Tainsu Stream, (TAD) = Downstream of Tainsu Stream, (SUU) = Upstream of Suten Stream, ( SUD) $=$ Downstream of Suten Stream, $($ NWU) = Upstream of Nwi River, $($ NWD) $=$ Downstream of Nwi River, $($ PRU) $=$ Upstream of Pra River, $($ PRD $)=$ Downstream of Pra River.

tive effects. Also, during the dry season, river mixing is very minimal and this prevents mercury in bottom layers of the rivers from coming to the surface to be volatilized.

None of the wet season total mercury concentrations exceeded the WHO guideline value $(1.0 \mu \mathrm{g} / \mathrm{L})$ for drinking water [12]. Even though that of the downstream of Tainsu River $(0.872 \mu \mathrm{g} / \mathrm{L})$ was considerably close. The lowest total mercury concentration recorded during the dry season was $0.248 \mu \mathrm{g} / \mathrm{L}$ in the River Pra.

The total mercury concentrations were higher in all the downstreams of the rivers/streams than the corresponding upstream. The difference is significant at $5.0 \%$ since probability calculated $(0.001)$ is less than 0.05 . This suggests that the gold recovery activities contribute immensely to the level of mercury in these water bodies, resulting in increased mercury concentrations downstream of each of the rivers/streams.

None of the upstream total mercury concentrations exceeded the WHO guideline value $(1.0 \mu \mathrm{g} / \mathrm{L})$ for drinking water [12]. The lowest upstream total mercury concentration of $0.045 \mu \mathrm{g} / \mathrm{L}$ was recorded in the Pra River during the rainy season whilst the highest $(0.412 \mu \mathrm{g} / \mathrm{L})$ was recorded in the River Suten during the dry season. The lowest downstream total mercury concentration of $0.282 \mu \mathrm{g} / \mathrm{L}$ was recorded in the Nkwasua River during the wet season and the highest $(1.343 \mu \mathrm{g} / \mathrm{L})$ which exceeds the WHO guideline value $(1.0 \mu \mathrm{g} / \mathrm{L})$ for drinking water was recorded in River Tainsu during the dry season.

Other downstream total mercury concentrations which were significant but lower than the WHO guideline value $(1.0 \mu \mathrm{g} / \mathrm{L})$ for drinking water [12] included Nkwasua $(0.987 \mu \mathrm{g} / \mathrm{L})$ during the dry season, Tainsu $(0.872 \mu \mathrm{g} / \mathrm{L})$ during the wet season and Nwi $(0.822 \mu \mathrm{g} / \mathrm{L})$ during the dry season.

In both the wet and dry seasons, trends in total mercury concentrations showed peak values at the downstream of River Tainsu. This may be due to the proximity of a gold processing site to the downstream of the river. There were very significant variations in the total mercury concentrations among the downstream sampling points (range $=0.282-1.343 \mu \mathrm{g} / \mathrm{L}$ ) than the upstream sampling points (range $=0.045-0.412 \mu \mathrm{g} / \mathrm{L}$ ) independent of the sampling time. These variations were most likely the result of the intensity of processing activities that take place along the individual rivers.

In comparing with other studies conducted in Ghana and other countries, the data available did not differentiate between wet and dry periods and therefore the comparisons are made between the means only. Table 2 gives the comparative results for water samples from the study area, other artisanal gold mining areas in Ghana with similar geology and three other known artisanal gold mining sites in the world. The Rivers Fena, Kwa- 
brafo, Kwame Tawia, Supu, San, Buama and Jimi are all located in the Offin Sub-basin of the Pra Basin. The rivers in the Talawan watershed (Indonesia) include Lotta, Pancuran IX, 'Sea', Malalayang, Paal II, Perumnas and Kilu. The Mutum Parana, Prainha, Humaita, Porto Velho and Cachoreira Rivers are all located in the South-western Amazon Basin where most gold mining activities in Brazil occur.

A comparison of the data from this study with that obtained by others at the River Pra basin in previous studies revealed that all the total mercury concentrations reported were relatively higher than those recorded at all the sampling points in this study $[15,16]$. The differences could be attributed to factors such as the length of time that gold processing has taken place in the rivers/streams, the period of sampling, the sample collection/handling procedures as well as analytical tools employed.

The total mercury concentrations in the river/stream water samples collected from the study area were relatively higher than values recorded) at the Talawan Watershed (Indonesia) [17]. Also, the total mercury concentrations in the South-western Amazon Basin (Brazil) were relatively lower compared to the study area whereas that of the Philippines (Mindanao Island, $754.00 \mu \mathrm{g} / \mathrm{L}$ ) far exceeds levels recorded in the study area.

\subsection{Total Mercury in Borehole Water}

In wet and dry seasons, trends in total mercury concentrations showed peak values at NYB1. This could be as a result of the proximity of NYB1 to the downstream of River Suten which also serves as a gold processing site. The mean mercury values for both seasons were 0.291 $\mu \mathrm{g} / \mathrm{L}$ (wet) and $0.420 \mu \mathrm{g} / \mathrm{L}$ (dry). The total mercury concentrations measured in the wet season were lower than the corresponding dry season concentrations with the exception of NYB1 where the wet season total mercury concentration $(0.619 \mu \mathrm{g} / \mathrm{L})$ was higher than the dry season total mercury concentration $(0.482 \mu \mathrm{g} / \mathrm{L})$. NYB1 recorded the highest dry season total mercury concentration of $0.482 \mu \mathrm{g} / \mathrm{L}$ whilst the lowest of $0.301 \mu \mathrm{g} / \mathrm{L}$ was recorded at NYB2. The lowest wet season total mercury concentration of $0.078 \mu \mathrm{g} / \mathrm{L}$ was measured at NOB2 and the highest $0.619 \mu \mathrm{g} / \mathrm{L}$ at NYB1. The difference in total mercury concentrations between the two seasons was insignificant at $5.0 \%$, since probability calculated $(0.096)$ is greater than 0.05 .

None of the total mercury concentrations exceeded the WHO guideline value $(1.0 \mu \mathrm{g} / \mathrm{L})$ for drinking water [12]. Measured total mercury concentrations in this study ranged from $0.078 \mu \mathrm{g} / \mathrm{L}$ to $0.619 \mu \mathrm{g} / \mathrm{L}$ in the wet season and from $0.301 \mu \mathrm{g} / \mathrm{L}$ to $0.482 \mu \mathrm{g} / \mathrm{L}$ in the dry season. This shows that there are variations among the various sampling sites in the total mercury concentrations measured in the wet season more than those measured in the dry season.

Table 3 gives the comparative results for borehole water samples from the study area, other mining areas in Ghana and artisanal gold mining sites located in the Talawan watershed of Indonesia.

A comparison of the data from this study with that obtained in a study at Obuasi and its surrounding communities show that all the total mercury concentrations reported were relatively higher than that recorded at all the sampling points in this study [15]. The differences could be attributed to factors such as the depth of the boreholes, soil type, proximity to gold processing sites as well as the length of time that gold mining has taken place in the areas. The mean total mercury concentrations in the borehole water samples collected from the study area were also relatively higher than all the known sites in Indonesia.

\subsection{Total Mercury in River/Stream Sediments}

Sediments represent an important component of aquatic ecosystems because of the niche and food source they provide for benthic aquatic organisms. The protection of sediment quality is therefore viewed as a logical and needed extension of water quality protection. All the total mercury concentrations measured in the dry season were higher than the corresponding wet season concentrations with the exception of the upstream of Rivers Nwi and Suten, Table 4. In the case of the upstream of River Nwi, the wet season total mercury concentration was $0.396 \mathrm{mg} / \mathrm{kg}$ and the dry season total mercury concentration was $0.381 \mathrm{mg} / \mathrm{kg}$. Also, the wet season total mercury concentration of the upstream of River Suten was 0.411 $\mathrm{mg} / \mathrm{kg}$ whereas the dry season concentration was 0.390 $\mathrm{mg} / \mathrm{kg}$. The difference in total mercury concentration between the wet and dry seasons was significant at 5.0\% since probability calculated (0.003) is less than 0.05 .

Two reasons may have contributed to this seasonal variation in total mercury concentration. The first is increased mining activities during the dry season with corresponding increase in mercury use. The other reason is the evaporation of surface water resulting in increased mercury concentrations in the water and sediments. During the study period, there was no evidence of increased mining activities. Increase in total mercury concentration can therefore be wholly attributed to evaporative effects. Also, during the dry season, river mixing is very minimal and this prevents mercury in bottom layers of the sediments from coming to the surface to be volatilized.

The total mercury concentrations of the upstreams and downstreams of all the rivers/streams during both the wet 
and dry seasons exceeded the US EPA guideline value of $0.2 \mathrm{mg} / \mathrm{kg}$ with the exception of the upstream of the Pra River $(0.134 \mathrm{mg} / \mathrm{kg})$ during the wet season. The total mercury concentrations were lower in all the upstreams of the rivers/streams than the corresponding downstreams. The difference is significant at $5.0 \%$ since probability calculated (0.001) is less than 0.05 . This may be as a result of the dumping of contaminated tailings and waste water into the water bodies, resulting in increased mercury concentrations in the sediments downstream of each of the rivers/streams.

The highest upstream total mercury concentration of $1.881 \mathrm{mg} / \mathrm{kg}$ was recorded in the Tainsu stream during the dry season whilst the lowest $(0.134 \mathrm{mg} / \mathrm{kg})$ was recorded in the Pra River during the rainy season. The highest downstream total mercury concentration of 4.886 $\mathrm{mg} / \mathrm{kg}$ was recorded in the Tainsu stream during the dry season and the lowest $(0.401 \mathrm{mg} / \mathrm{kg})$ was recorded in the Pra River during the wet season. Other downstream total mercury concentrations which were very significant include Nkwasua $(4.745 \mathrm{mg} / \mathrm{kg})$ and Suten $(3.769 \mathrm{mg} / \mathrm{kg})$ during the dry season.

In both the wet and dry seasons, trends in total mercury concentrations showed peak values at the downstream of Tainsu and Nkwasua streams, Figure 5. This could be attributed to the fact that the downstream of both streams are very close to gold processing sites. There were very significant variations in the total mercury concentrations among the downstream sampling points (range $=0.401-4.886 \mathrm{mg} / \mathrm{kg}$ ) more than the upstream sampling points (range $=0.134-1.881 \mathrm{mg} / \mathrm{kg}$ ) independent of the sampling time. The differences in intensity of processing activities that take place along the individual rivers may have accounted for this.

Generally, metals in sediments do not have immediate implications for human health as long as humans do not consume these sediments directly, but they can have serious consequences when they enter the food chain. Table 4 gives the comparative results for sediment samples from the study area, other mining areas in Ghana with similar geology and three other known artisanal gold mining sites located in Brazil, Indonesia and Philippines.

A comparison of the data from this study with another on the Upper and Lower Pra [16]. revealed that the total mercury concentrations measured at all sampling points in this study exceeded the concentrations in the Upper Pra $(0.018 \mathrm{mg} / \mathrm{kg})$, the Lower Pra $(0.026 \mathrm{mg} / \mathrm{kg})$ and the Offin $(0.023 \mathrm{mg} / \mathrm{kg})$ Rivers. Another comparison with a study showed differential variation among the total mercury concentrations [15]. The difference could probably be due to differences in the length of time that gold processing has taken place in the rivers/streams, sediment grain size, organic matter content, sampling seasons, the sample collection/handling procedures as well as analytical tools employed.

Compared with other active AGM sites in the world, the mean mercury values obtained in the study sediments were higher than that of Brazil, but lower than that of the Philippines and Indonesia.

\section{Acknowledgements}

Our sincere thanks go to Mr. Felix Okyere Amoah of Land-tech Engineering Ltd. for helping pick all the GPS coordinates and also Mr. H. Komladzei of the Map Room of the Water Research Institute for drawing all the maps in this work. We also appreciate the role played by Messrs Michael Dzorleku and Michael Afram Danquah of the Environmental Chemistry Laboratory of the Water Research Institute in the analyses. The role played by the field assistants Messrs Agyarko Ayeh Asiedu and Daniel Asomani is acknowledged

\section{REFERENCES}

[1] O. Bermudez-Lugo, “Gold Fields Mineral Survey,” In: Ghana Chamber of Mines Factoid 2008, Ghana Chamber of Mines, Accra, 2008.

[2] B. K. Ntibery, E. Atorkui and B. N. A. Aryee, “Trends in Small-Scale Mining of Precious Minerals in Ghana: A Perspective on its Environmental Impact," Journal of Cleaner Production, Vol. 11, 2003, pp. 131-140. doi:10.1016/S0959-6526(02)00043-4

[3] G. Hilson, "A Contextual Review of the Ghanaian Small-Scale Mining Industry," Mining, Minerals and Sustainable Development (MMSD), Vol. 76, 2001, pp. 2-30.

[4] J. Heintz, "Employment, Poverty and Gender in Ghana," Political Economy Research Institute, University of Massachusetts, Amherst, Working Paper Series No. 92, 2005.

[5] E. H. Mcdonald, "Alluvial Mining: The Geology, Technology and Economics of Placers,” Chapman and Hall, London, 1983, p. 508.

[6] K. H. Telmer and M. M. Veiga, "World Emissions of Mercury from Artisanal and Small Scale Gold Mining," In: Mercury Fate and Transport in the Global Atmosphere: Measurements, Models and Policy Implications, Interim Report of the UNEP Global Mercury Partnership, Mercury Transport and Fate Research Partnership Area, Accessed on 14 July 2008. http://www.cs.iia.cnr.it/UNEP-MFTP/index.htm

[7] Birim North District Assembly, "Birim North District Profile,” An Unpublished Document, 2006.

[8] G. O. Kesse, "The Mineral and Rock Resources of Ghana,” A. A. Balkema Publisher, Rotterdam, 1985.

[9] J. S. Kuma, "Is Groundwater in the Tarkwa Gold Mining 
District of Ghana Potable?” Environmental Geology, Vol. 45, No. 3, 2004, pp. 391-400. doi:10.1007/s00254-003-0888-9

[10] Anonym, "Preventive Measures against Environmental Mercury Pollution and Its Health Effects,” Japan Public Health Association, 2001.

[11] APHA, AWWA \& WEF, "Standard Methods for the Examination of Water and Wastewater," 20th Edition, Washington D.C., 1998.

[12] WHO, “Guidelines for Drinking-Water Quality,” 4th Edition, World Health Organization, Geneva, Switzerland. 2006.

[13] E. R. Long, D. D. MacDonalds, S. L Smith and F. D Calder, "Incidence of Adverse Biological Effects within Ranges of Chemical Concentrations in Marine and Estuarine Sediments," Environmental Management, Vol. 19, No. 1, 1995, pp. 81-97. Accessed on line 4 April 2010. http://water.epa.gov./polwaste/sediments/guidelines.cfm

[14] M. Macklin, "Metal Contaminated Soils and Sediment: A Geographical Perspective,” In: M. Newson, Ed., Managing the Human Impact on the Natural Environmental Patterns and Processes, Belhaven Press, London, 1992, pp. 173-193.

[15] T. M. Akabzaa, J. S. Seyire and K. Afriyie, "The Glitter- ing Façade: Effects of Mining Activities on Obuasi and its Surrounding Communities,” Third World NetworkAfrica, 2007.

[16] A. K. Donkor, V. K. Nartey, J. C. Bonzongo and D. K. Adotey, "Artisanal Mining of Gold with Mercury in Ghana,” West Africa Journal of Applied Ecology, Vol. 9, 2006, 8 Pages.

[17] D. Limbong, J. Kumampung, I. F. M. Rumengan, T. Arai and N. Miyazaki, "Measurement of Total Mercury Concentration in the Water Source Pool of Public Drink Water Installations around Manado City, North Sulawesi, Indonesia. Otsuchi,” Marine Science, Vol. 28, 2003, pp. 99-101.

[18] C. Aspinall, "Small-Scale Mining in Indonesia," Mining, Minerals and Sustainable Development (MMSD), Vol. 79, 2001, pp. 2-30.

[19] G. Drasch, S. Böse-O’Reilly, C. Beinhoff, G. Roider and S. Maydl, "The Mt. Diwata Study on the Philippines 1999-Assessing Mercury Intoxication of the Population by Small-Scale Gold Mining," The Science of the Total Environment, Vol. 267, 2001, pp. 151-168. doi:10.1016/S0048-9697(00)00806-8 